\title{
Kontrola okratoksina A u sušenom voću
}

1 Robert Kecerin

1 Marinko Petrović

1 Ivana Prskalo

1 Vedran Jagić

1 Dario Lasić

1 Nastavni zavod za javno zdravstvo „Dr. Andrija Štampar”

\section{Sažetak}

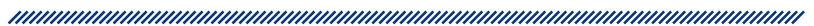

Okratoksini su podgrupa mikotoksina koje stvaraju plijesni iz roda Aspergillus ochraceus i Penicillium viridicatum. Najpoznatiji je i najtoksičniji okratoksin A, manje je toksičan okratoksin $\mathrm{B}$, a okratoksin $\mathrm{C}$ dobiven je samo u laboratorijskim uvjetima. Na pokusnim životinjama dokazan je nefrotoksičan, karcinogen, teratogen te imunosupresivan učinak okratoksina $\mathrm{A}$, a novija istraživanja dokazuju da ima i štetan učinak na reproduktivno zdravlje ljudi. Najčešće se stvara na usjevima nakon žetve ako govorimo o žitaricama, ali predstavlja znatan zdravstveni te gospodarski problem i u proizvodnji, preradi, skladištenju i distribuciji drugih kultura kao što su začini, kava, mahunarke, orašasti plodovi, vino, pivo, sušeno voće i sl.

S obzirom na to da sadrži niz vrijednih hranjivih tvari (polifenoli, vlakna, vitamini, minerali, šećeri i sl.), sušeno se voće proizvodi diljem svijeta pa u mnogim zemljama čini znatan udio u poljoprivrednoj proizvodnji i gospodarstvu općenito. Pojava plijesni, a posljedično i okratoksina A predstavlja najveći problem u uzgo- ju, proizvodnji i distribuciji ovakve vrste hrane. Valja imati na umu da zaštita proizvoda od pojave plijesni i stvaranja mikotoksina započinje već na samoj plantaži i potrebno ju je kontinuirano provoditi kroz različite proizvodne i manipulativne faze (prilikom dozrijevanja ploda, pri berbi, kod sušenja, transportiranja, skladištenja itd.).

Udio mikotoksina u sušenom voću, kao i u ostaloj hrani koja se stavlja na tržište, određuje se osjetljivim analitičkim metodama, ponajprije testom ELISA, koji je orijentacijska metoda, te HPLC-om i LC-MS/MS-om, koji su potvrdne metode. Vjerodostojnost analitičke metode usko je povezana s uzimanjem uzorka na ispravan način, kao i njegovom dobrom homogenizacijom.

Ključne riječi: mikotoksini, okratoksin A, sušeno voće, HPLC

Datum primitka: 16.07.2018.

Datum prihvaćanja: 07.10.2018.

DOI: $10.24141 / 1 / 4 / 2 / 9$

Adresa za dopisivanje:

Robert Kecerin

Nastavni zavod za javno zdravstvo „Dr. Andrija Štampar”

Mirogojska cesta 16, 10000 Zagreb

tel.: +385914678065

e-pošta: robert.kecerin@stampar.hr 


\section{Uvod}

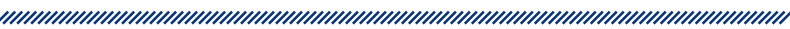

Plijesni su velika skupina mikroskopskih gljivica čije je tijelo građeno od gustog sustava cjevastih stanica bez klorofila, hifa, koje su nitaste građe i obično bezbojne. Isprepletene niti hifa tvore micelij koji se kao paučinasta, prašnjava prevlaka rasprostire po podlozi. Razmnožavaju se većinom s pomoću spora, iako se mogu razmnožavati i vegetativno, gdje nove kolonije nastaju od fragmenata hifa.1

Plijesni imaju gospodarsku važnost za čovjeka, neke se upotrebljavaju u proizvodnji antibiotika i u prehrambenoj industriji, primjerice u proizvodnji sira ili određenih fermentiranih suhomesnatih proizvoda. Međutim, plijesni većinom uzrokuju štete u gospodarstvu. Danas je poznato oko 100000 vrsta plijesni. Od njih se više od 400 vrsta smatra toksičnima, a za $5 \%$ je poznato da proizvode toksične tvari, koje se nazivaju mikotoksinima, a koje imaju neželjen učinak kako na životinje tako i na čovjeka. ${ }^{2}$ Prema Organizaciji za hranu i poljoprivredu Ujedinjenih naroda (FAO, engl. Food and Agriculture Organisation of the United Nations), pretpostavlja se da je $25 \%$ usjeva diljem svijeta kontaminirano plijesnima i posljedično mikotoksinima te se gubici mjere u milijardama dolara. ${ }^{3}$

Plijesni su klasificirane kao drugi po štetnosti uzročnik propadanja proizvoda tijekom skladištenja, odmah nakon insekata i drugih štetočina. ${ }^{4}$ Tako je u nekim saveznim državama SAD-a procijenjen gubitak od 100 milijuna dolara do ukupno 1,6 milijardi dolara zbog kontaminacije plijesnima i mikotoksinima. Afrička poljoprivreda pretrpi godišnje gubitke od 670 milijardi dolara zbog međunarodnih barijera i zabrana u plasmanu mikotoksinima kontaminirane hrane. ${ }^{2}$

Podjela plijesni s obzirom na vrijeme i mjesto kontaminacije na biljkama i plodovima:

1. plijesni s polja

2. plijesni u skladištima

3. plijesni uznapredovalog kvarenja.

Mikotoksini (grč. mykes - gljiva, toxicon - otrov) su toksični, sekundarni metaboliti plijesni za koje se smatra da nemaju ulogu u rastu i razvoju plijesni, nego im služe kao obrana od drugih mikroorganizama. ${ }^{5}$ Bolesti koje uzrokuju mikotoksini nazivaju se mikotoksikoze. Mikotoksikoze su, dakle, alimentarna trovanja ljudi i životi- nja toksičnim proizvodima plijesni (mikotoksinima) čija težina ovisi o toksičnosti samog mikotoksina, trajanju izloženosti, dobi, spolu te dosta slabo razjašnjenim sinergističkim učincima koji uključuju genske predispozicije i međudjelovanja s ostalim toksičnim tvarima. Također loš vitaminski status, malnutricija, ekscesivno uzimanje alkohola te trenutačne infekcije mogu biti čimbenici koji utječu na težinu kliničke slike mikotoksikoze. Isto tako, mikotoksikoze mogu povećati osjetljivost na mikrobne infekcije, pogoršati posljedice malnutricije ili sinergistički djelovati s drugim toksinima. ${ }^{6}$

Od 60-ih godina prošlog stoljeća do danas otkriveno je oko 400 različitih mikotoksina. U ljudi i životinja mikotoksini mogu imati akutnu ili kroničnu toksičnost. Kronična toksičnost može se manifestirati kao karcinogeni, mutageni i teratogeni učinak. Sa zdravstvene strane, važni mikotoksini koji se mogu nalaziti u hrani jesu: aflatoksini, okratoksini, trihoteceni, fumonizini, zearalenon. ${ }^{7} \mathrm{~S}$ akutnim mikotoksikozama povezuju se aflatoksini, fumonizini i ergot alkaloidi, kako u čovjeka tako i kod stoke. Budući da su mikotoksini općenito dosta male molekule, one ne aktiviraju imunološki sustav, stoga je ljudski organizam trajno nezaštićen od mikotoksina. ${ }^{5}$ Mikotoksikoze, posebno akutne, češće su u veterinarskoj praksi zbog toga što se životinje u uzgoju hrane krmivom koje je biljnog podrijetla, a kontaminirano je mikotoksinima. Dok životinje direktno obole uzimajući takvu onečišćenu hranu, ljudi obole indirektno hraneći se proizvodima životinja koji sadrže mikotoksine (mlijeko, meso, jaja) ili putem dišnog sustava.

Mikotoksikoze se odlikuju sljedećim značajkama:

- nisu kontagiozne (ne prenose se na ljude i životinje)

- uvijek su povezane s hranom

- ne liječe se antibioticima

- slične su avitaminozama. ${ }^{1}$

\section{Okratoksin $\mathrm{A}$}

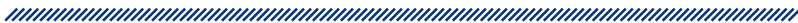

Okratoksin A (OTA) jedan je od najviše proučavanih mikotoksina, kako zbog različitih vrsta hrane u kojima se pojavljuje tako i zbog njegove rasprostranjenosti diljem svijeta.8,9 Umjereno je stabilan te u određenoj mjeri može podnijeti većinu postupaka u preradi hrane. Za- 


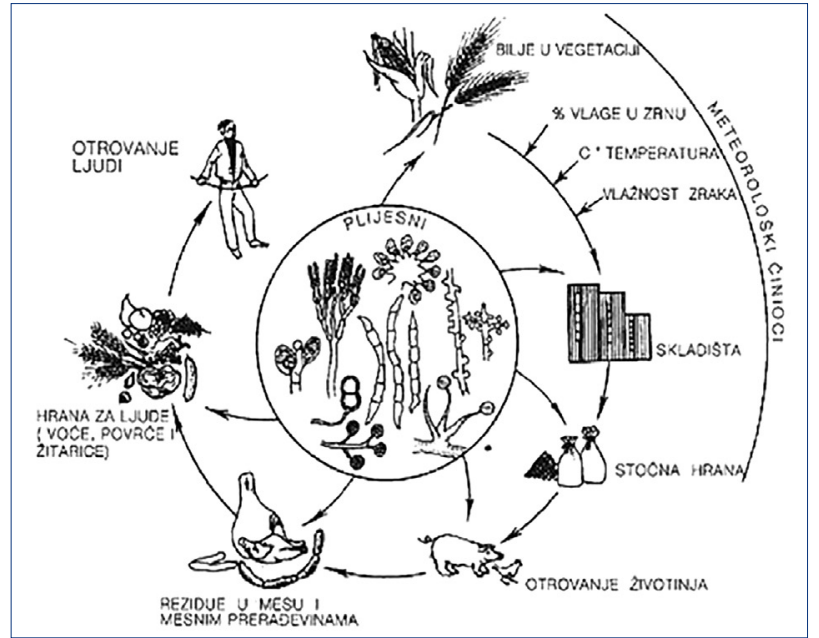

Slika 1. Put mikotoksina u hranidbenom lancu Izvor: http://www.hah.hr/sto-su-mikotoksini/

jednički je naziv za bolesti izazvane negativnim učincima okratoksina okratoksikoze.

Prisutnost okratoksina A utvrđena je u mnogim vrstama hrane širom svijeta kao što su mahunarke, ${ }^{10}$ žitarice, ${ }^{11}$ hrana životinjskog porijekla, ${ }^{10}$ kakao, ${ }^{10}$ sok od grejpa, ${ }^{10,12}$ zelena kava, ${ }^{13}$ kruh, ${ }^{14}$ sušeno voće, ${ }^{15}$ vino, pivo te voćni sokovi. ${ }^{16}$ Od zemalja iz kojih postoje izvješća o pojavi okratoksina A navode se Španjolska, ${ }^{17}$ Nizozemska, ${ }^{18}$ Francuska, ${ }^{19}$ Tunis, ${ }^{8}$ Češka, ${ }^{20}$ Egipat, ${ }^{21}$ Argentina, ${ }^{22}$ Maroko ${ }^{23}$ i Australija. ${ }^{24}$ Osim kroz sažetak navedenih i nedvojbeno utvrđenih negativnih učinaka po ljudsko zdravlje, provedena su neka istraživanja koja pobuđuju sumnju da konzumiranje hrane kontaminirane okratoksinom A u trudnoći i/ili tijekom djetinjstva može izazvati pojavu karcinoma testisa tijekom puberteta. ${ }^{25,31}$

S obzirom na to da su bubrezi jedni od ciljnih organa što se tiče djelovanja okratoksina A, potrebno je spomenuti balkansku endemsku nefropatiju (BEN), kao i povećanu pojavnost tumora mokraćnog sustava, za koje se sumnja da su također izazvani utjecajem spomenutog, premda za to još uvijek nedostaje epidemioloških dokaza koji bi nedvojbeno utvrdili odgovornost okratoksina A.26 Premda novija istraživanja vezana za BEN u drugi plan stavljaju okratoksin A i znatnu prednost što se tiče nastanka spomenute bolesti daju aristolohičnoj kiselini, tvari koja se nalazi u stabljici i listu biljke iz roda Aristolochia (vučja stopa), sinergijske učinke koje ta dva spoja zajedno s ostalim čimbenicima (okolišni, genski, prehrambene navike i sl.) mogu izazvati u pojavnosti balkanske endemske nefropatije ne bi trebalo u potpunosti odbaciti. 27,28

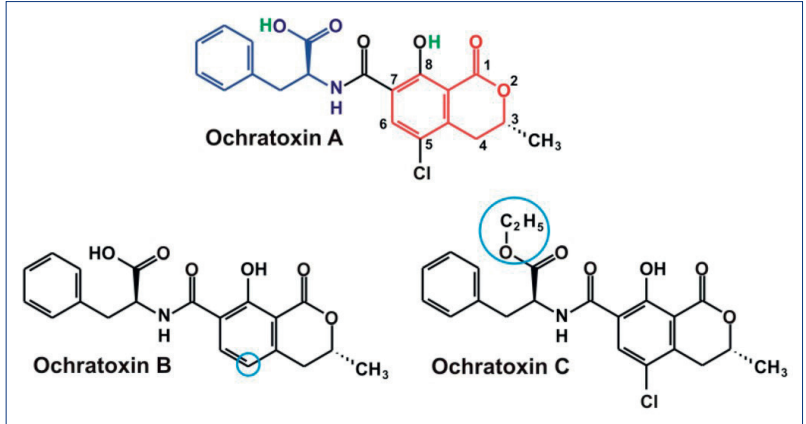

Slika 2. Prikaz struktura različitih vrsta okratoksina

Izvor: http://www.mdpi.com/2072-6651/8/4/111/htm

\subsection{Novija istraživanja povezana s okratoksinom A u sušenom voću}

U radu objavljenom 2015. godine Palumbo i sur. u raznim su dijelovima SAD-a u razdoblju od 2012. do 2014. godine istraživali pojavu okratoksina A u sušenom voću i orašastim plodovima. Pritom je analizirano 665 uzoraka uzetih u malim trgovinama ili velikim trgovačkim centrima u originalnom pakiranju ili u rasutom obliku (rinfuzno). Okratoksin A utvrđen je u 48 uzoraka grožđica, četiri uzorka smokava i u jednom uzorku datulja. Razine OTA u spomenutim uzorcima bile su u rasponu od 0,28 do 15,34 ng/g. Metodom PCR (engl. Polymerase Chain Reaction) utvrđena je prisutnost različitih vrsta aspergilusa u proizvodima u kojima su nađene povišene razine okratoksina A. Najučestaliji tip bio je Aspergillus carbonarius. Rezultati istraživanja sugeriraju da su grožđice češće od ostalog sušenog voća kontaminirane niskim razinama okratoksina $A$ nastalim djelovanjem različitih vrsta aspergilusa. ${ }^{29}$

U radu objavljenom 2013. godine o istraživanju koje je provela Kollia sa suradnicima analizirano je 26 uzoraka sušenog grožđa s grčkog tržišta. Primjenom metoda ELISA i HPLC utvrđena je prisutnost okratoksina A u svim uzorcima. Prosječna razina kontaminanta u uzorku bila je 47,2 $\mu \mathrm{g} / \mathrm{kg}$. Šest uzoraka bilo je kontaminirano visokim razinama (medijan 120,6 $\mu \mathrm{g} / \mathrm{kg}$ ), u 18 uzoraka premašen je MDK kod zakonske regulative EU-a $(10 \mu \mathrm{g} / \mathrm{kg}) .^{30}$

$\mathrm{U}$ istraživanju Nayebpoora i suradnika sa sveučilišta u Sharekordu objavljenom 2013. godine, prvom takve vrste koje je provedeno u Iranu, utvrđena je prisutnost okratoksina A u sirovom i suhom voću te orašastim plodovima. Ukupno je uzeto 134 uzorka grožđica i suhih smokava u velikim trgovačkim centrima u jednoj pokrajini. Analiza je provedena metodom HPLC, a utvrđeno je da je OTA bio 
prisutan u 10,41 \% uzoraka grožđica (pet uzoraka) odnosno u $14,73 \%$ uzoraka suhih smokava (17 uzoraka). Zaključeno je da taj podatak predstavlja veliki javnozdravstveni problem, a istodobno prisutnost okratoksina $\mathrm{A} u$ hrani znatno smanjuje njezinu hranjivu vrijednost. ${ }^{31}$

lako to nije primarna tema ovog rada, u želji da se što više približi i naglasi raširenost problema vezanih uz OTA, ali i uz mikotoksine općenito, uz navedena nije na odmet spomenuti i sljedeće istraživanje. Naime, u radu koji je objavljen 2015. godine Solfrizzo je sa suradnicima istraživao prisustvo okratoksina $\mathrm{A}$ u tropu vinove loze s obzirom na to da se sve više upotrebljava kao vrijedna sirovina u proizvodnji biljnih dodataka prehrani, prehrambenih bojila i tartarata. Pritom je važno napomenuti da postoji znatan rizik prisutnosti okratoksina A u spomenutoj sirovini. U provedenom istraživanju analizirano je 24 uzorka biljnih dodataka prehrani i 13 prehrambenih bojila dobivenih od vinove loze. ${ }^{32}$ OTA je pronađen u $75 \%$ uzoraka biljnih dodataka prehrani u razinama od $<1,16$ do $20,23 \mu \mathrm{g} / \mathrm{kg}$ i u $69 \%$ uzoraka prehrambenih bojila u razinama od $<1,16$ do $32,00 \mu \mathrm{g} /$ kg. $U$ četiri komercijalna dodatka prehrani s laksativnim učinkom OTA nije utvrđen. U osam uzoraka prikupljenih u dvije vinarije koje upotrebljavaju trop i vinski talog za dobivanje tartarata i drugih proizvoda OTA je utvrđen u razinama od $<1,16$ do $240,93 \mu \mathrm{g} / \mathrm{kg}$. Učestala pojavnost okratoksina A u navedenim proizvodima dobivenima od spomenutih sirovina dovodi do potrebe za utvrđivanjem najviših dopuštenih razina mikotoksina u njima. ${ }^{32}$

Kanapitsas i sur. u radu iz 2016. godine opisali su učinak gama-zračenja u dozama od 10 kGy na stvaranje okratoksina A od plijesni Aspergillus carbonarius na grožđicama. Utvrđeno je da gama-zračenje u spomenutoj dozi reducira kontaminaciju razine od $100 \mathrm{ng}$ okratoksina $\mathrm{A}$ za približno $88 \%$ u usporedbi s neozračenim uzorcima grožđica. Izlaganje zračenju vršeno je nakon 12 dana inkubacije plijesni. Prisutnost okratoksina A analizirana je metodom HPLC s fluorescentnim detektorom (FD). Iskorištenje metode bilo je $104 \%$, granica detekcije bila je 0,26 ng/g i granica kvantifikacije bila je 0,51 ng/g. Razvijanje rješenja u tom pravcu u cilju smanjenja razine kontaminiranosti u prehrambenim proizvodima od sušenog voća moglo bi u znatnoj mjeri ublažiti posljedice koje trpe subjekti u poslovanju s hranom zbog šteta izazvanih općenito mikotoksinima. ${ }^{33}$

\subsection{Okratoksin A u sušenom voću}

Sušeno je voće prehrambeni proizvod iz kojeg je prirodnim ili pak umjetnim putem uklonjena voda u cilju da ga se sačuva od kvarenja odnosno da mu se produži rok trajanja. Zbog svojeg okusa, sadržaja hranjivih tvari i trajnosti razne vrste sušenog voća smatraju se vrlo cijenjenom namirnicom. Na našem tržištu postoji velik broj takvih proizvoda. Neki su od njih grožđice, brusnice, smokve, banane, šljive, marelice, datulje i sl.

Proizvodnja sušenog voća ima vrlo dugu tradiciju i seže unazad 6000 godina u područje Mezopotamije. S obzirom na prethodno spomenuto valja naglasiti da uzgoj i proizvodnja sušenog voća čini znatan udio u poljoprivrednoj proizvodnji, a time ukupno i u gospodarstvima mnogih zemlja, zato je od iznimne važnosti osigurati da spomenuti proizvodi na tržište dođu kao sigurni, to jest da ne ugrožavaju zdravlje potrošača te da budu prikladni za ljudsku potrošnju. lako su se u prošlosti uzgoj, proizvodnja i izvoz sušenog voća povezivali s područjem Mediterana, u današnje su se vrijeme uzgoj i proizvodnja spomenutih proizvoda proširili i u druge dijelove svijeta (grafikon 3).

Premda plodovi sušenog voća zbog svojeg sastava (visoka kiselost i udio šećera te nizak udio vode) nisu skloni bakteriološkom kvarenju, podržavaju rast i razvoj raznih plijesni, od kojih neke mogu proizvesti mikotoksine. Stoga možemo zaključiti da su plijesni najvažniji čimbenik u ugrozi sigurnosti spomenutih prehrambenih proizvoda, a time i izravno u stvaranju velikih ekonomskih šteta. Tome u prilog govori i niz izvješća u kojima se otkriva učestalo pojavljivanje visokih razina kontaminacije tih prehrambenih proizvoda mikotoksinima, što za posljedicu ima velike gospodarske gubitke. ${ }^{34}$

Broj prijava u sustav RASFF također nam može približiti razmjere problema izazvanih mikotoksinima (grafikon 1 ).

Pojava gljivične infekcije na plodovima moguća je u različitim proizvodnim i manipulativnim fazama (prilikom dozrijevanja ploda, pri berbi, kod sušenja, transportiranja, skladištenja itd.). ${ }^{35,36}$ Rast plijesni te posljedično stvaranje mikotoksina u plodu ovisi o složenom međudjelovanju kako unutarnjih (sadržaj vlage, aktivitet vode, pH-vrijednost, redoks-potencijal, sadržaj hranjivih tvari, osmotski tlak) tako i vanjskih čimbenika (fizička oštećenja, utjecaj okoline). Slijedom navedenog dolazimo do zaključka da učinkovita borba u cilju smanjivanja plijesni, kao i njihovih metabolita općenito, počiva u međudisciplinarnoj suradnji različitih struka (agronoma, prehrambenih tehnologa, djelatnika sanitarnih struka, liječnika, biologa, kemičara i sl.) te aktivnoj primjeni učinkovitih mjera, počevši od samog nasada dok je plod još na drvetu te nadalje kroz postupke berbe, prebiranja oštećenih plodova, sušenja prirodnim meto- 


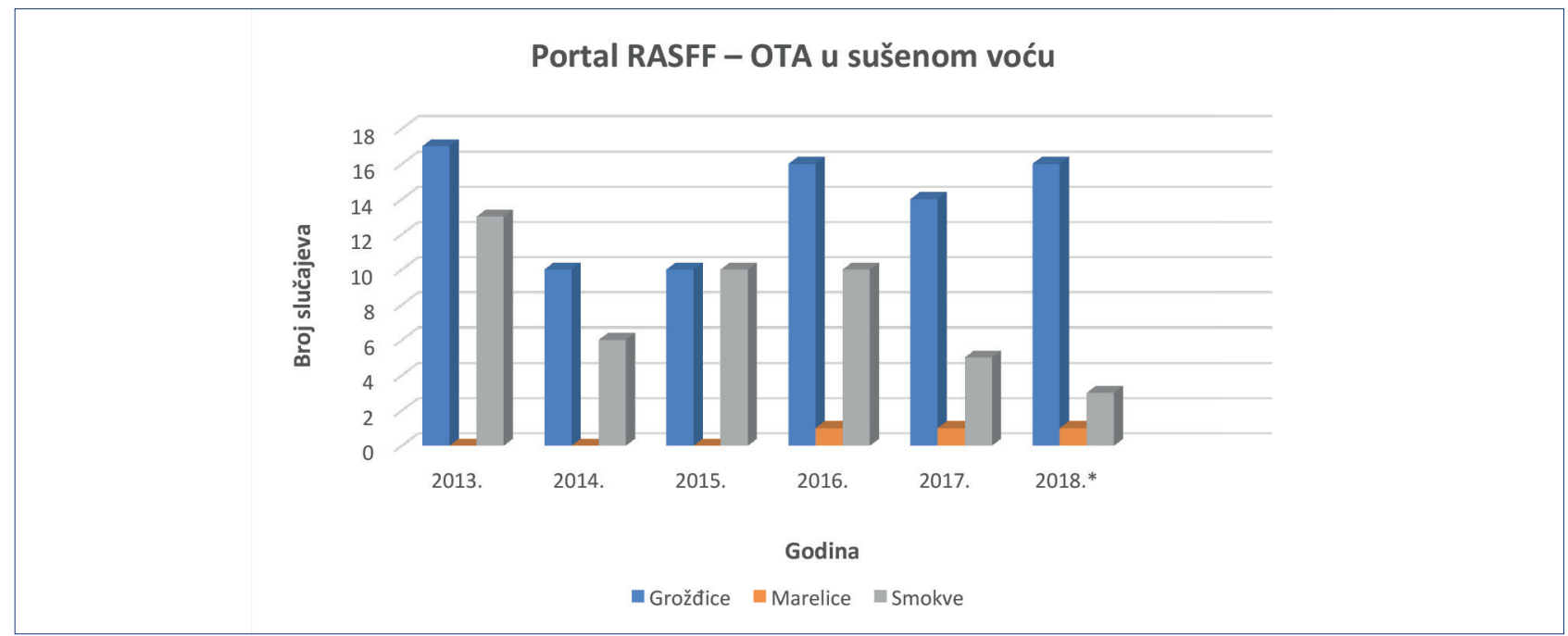

Grafikon 1. Pojavnost okratoksina A u posljednjih nekoliko godina

* Napomena: Već u prvoj polovini 2018. godine pojavio se statistički značajan broj prijava na portalu RASFF.

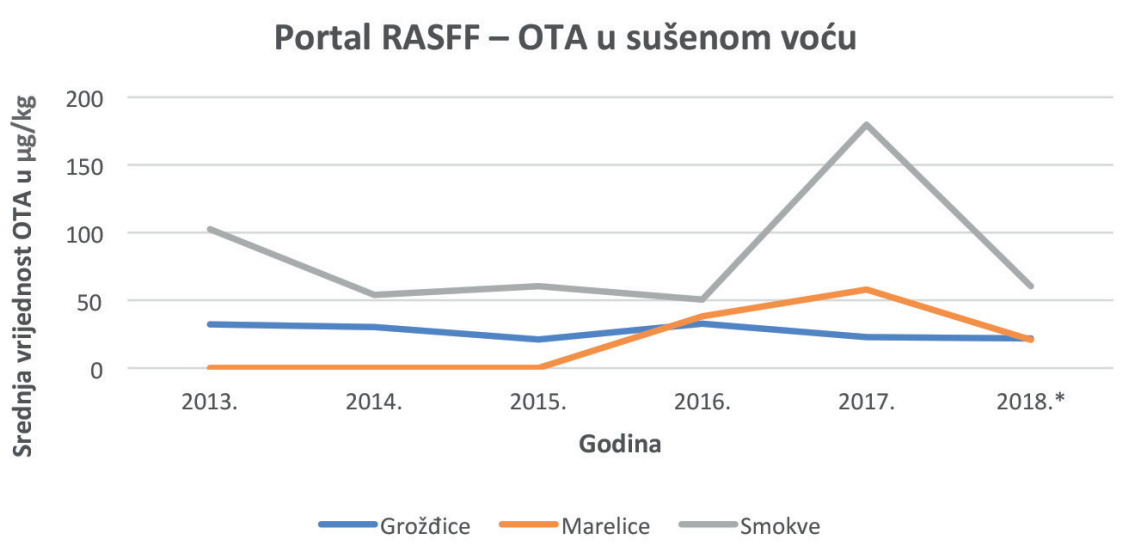

Grafikon 2. Prikaz godišnje srednje vrijednosti okratoksina A u sušenom voću

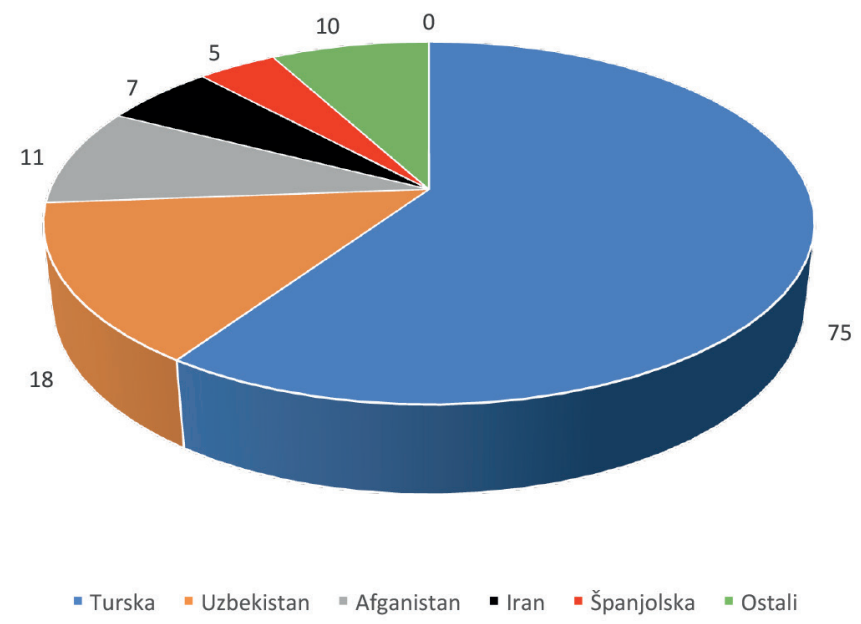


dama, zaštite od štetnika, transporta, skladištenja te na kraju samoga kupca.

Također je važno istaknuti da kvalitetno uspostavljena dobra poljoprivredna praksa (GAP), dobra proizvođačka praksa (GMP), dobra higijenska praksa (GHP), dobra distribucijska praksa (GDP) te njihov racionalno uspostavljen međuodnos objedinjen adekvatno uspostavljenim sustavom HACCP nedvojbeno umanjuju rizike po zdravlje populacije, kao i znatne gospodarske štete izazvane negativnim djelovanjem mikotoksina. ${ }^{31}$

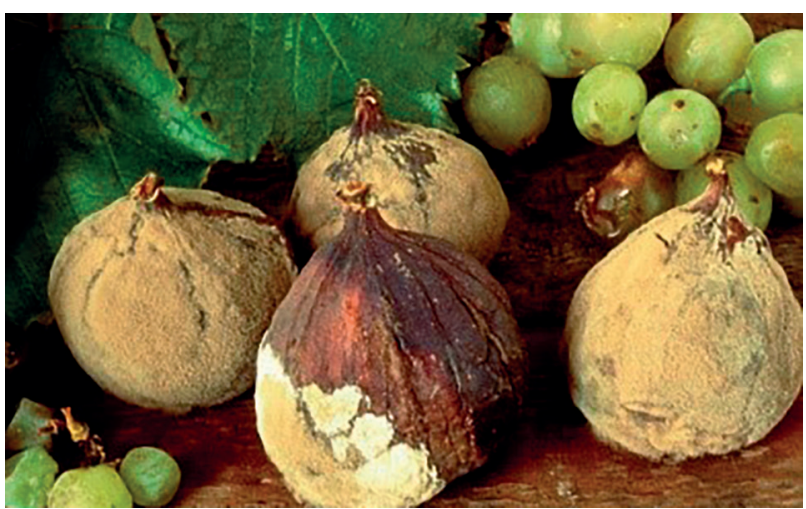

Slika 3. Izgled smokava zahvaćenih plijesnima Izvor: https://olfactoryobsessed.wordpress.com/2011/11/17/myunpleasant-experience-with-aftelier-fig/

\section{Materijali i metode}

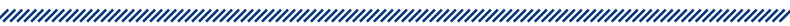

\subsection{Materijali}

Od svih koraka u analizi, tj. analitičkom procesu, uzorkovanje zauzima vrlo važno mjesto. Način uzimanja uzorka može znatno utjecati na cijeli analitički postupak, kao i točnost dobivenog rezultata. Stoga je veoma važno voditi računa o njegovoj reprezentativnosti jer će u suprotnom rezultat analize sadržavati sustavnu pogrešku. Da bi uzorak bio reprezentativan te da bi se mogla utvrditi stvarna koncentracija okratoksina A u sušenom voću, potrebno je ispravno provesti postupak uzimanja uzoraka. Iz tog razloga bitno je postupak uzimanja uzorka u potpunosti uskladiti s Uredbom komisije (EZ) br. 401/2006. o utvrđivanju metoda uzorkovanja i analize za službenu kontrolu razina mikotoksina u hrani.

Uzorkovanje na tržištu isključivo se provodi u:

- proizvodnji

- preradi

- veleprodaji

- skladištima gdje se nalaze cijeli lotovi/šarže (i u hipermarketima).

\subsubsection{Postupak uzorkovanja sušenog voća u rasutom obliku}

S obzirom na to da su mikotoksini općenito prilično raspršeni (heterogeni) u seriji te nestručno ili nepravilno uzimanje uzoraka može dovesti do netočnih rezultata laboratorijskih analiza, kod ovakvog načina uzimanja uzorka od iznimne je važnosti poštivati zahtjeve Uredbe komisije (EZ) br. 401/2006. Stoga je potrebno posebnu pažnju posvetiti samom postupku uzimanja uzoraka koristeći se pritom odgovarajućom opremom i vodeći računa da se svaki pojedinačni uzorak zasebno pakira u odgovarajuće označenu vrećicu. Sve pojedinačne zasebno pakirane vrećice potrebno je transportirati do laboratorija zaštićene od svjetlosti.

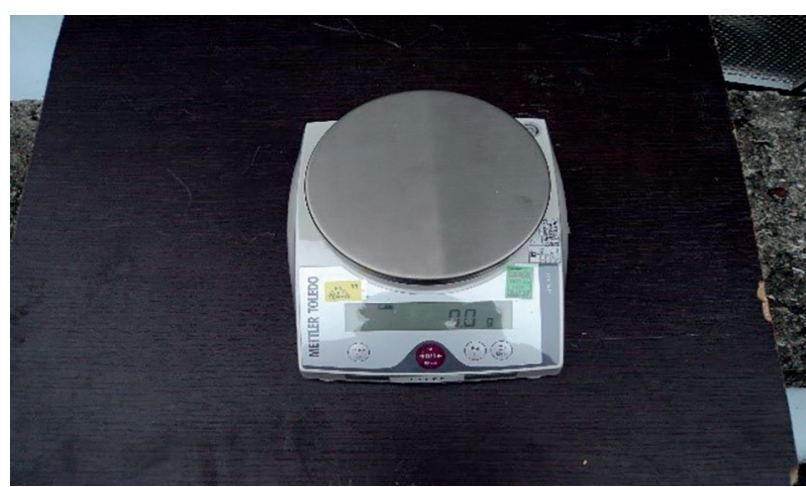

Slika 4. Umjerena vaga za vaganje uzoraka pri uzorkovanju Izvor: Jagić, Kecerin (2018.)

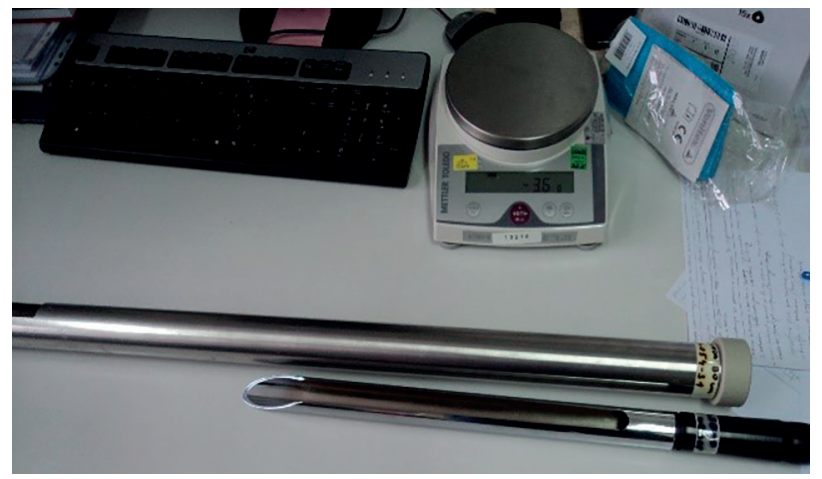

Slika 5. Sonda za uzimanje rasutog uzorka Izvor: Jagić, Kecerin (2018.) 


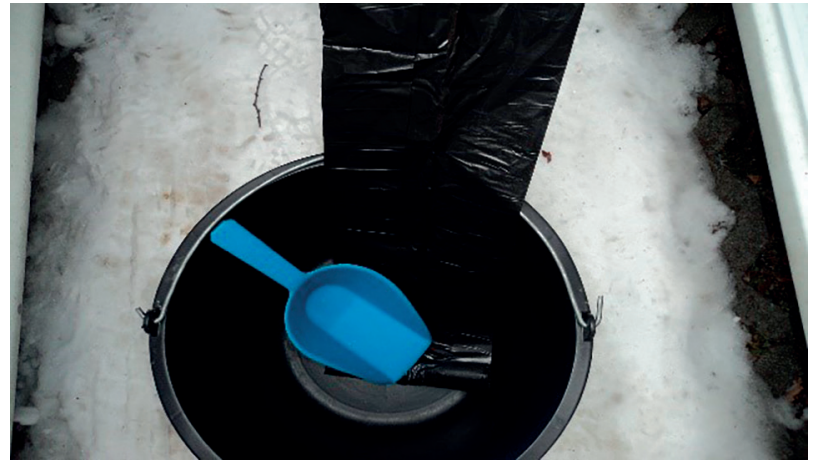

Slika 6. Pribor za uzimanje sušenog voća u rasutom obliku Izvor: Jagić, Kecerin (2018.)

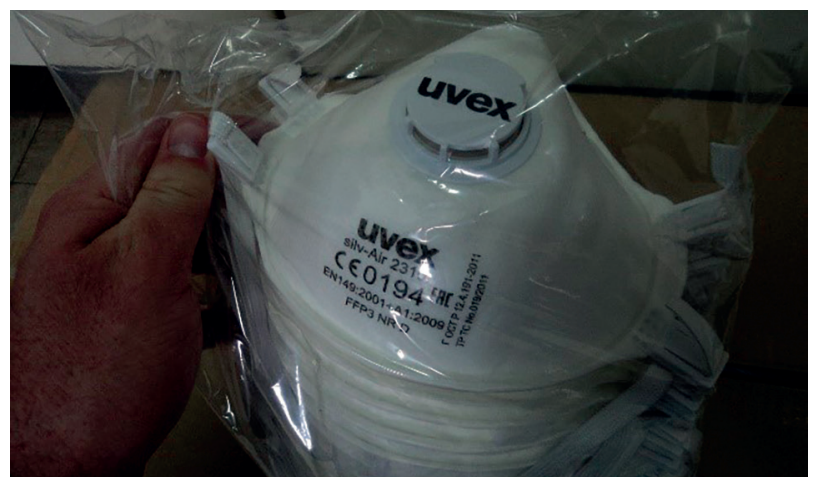

Slika 7.

Izvor: Jagić, Kecerin (2018.)

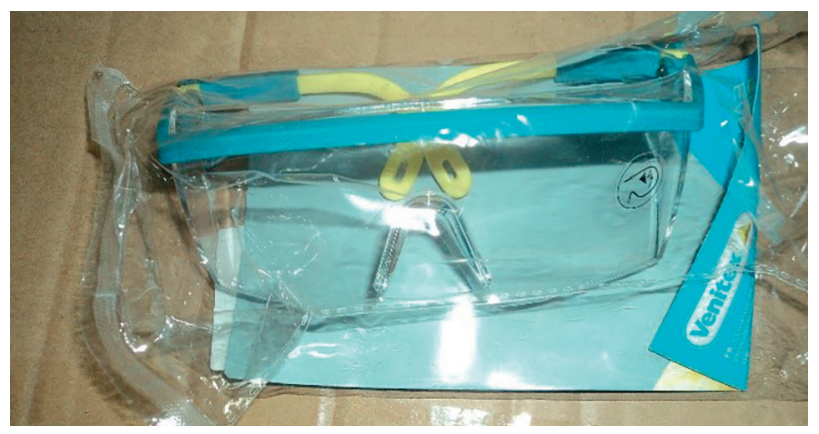

Slika 8.

Izvor: Jagić, Kecerin (2018.)

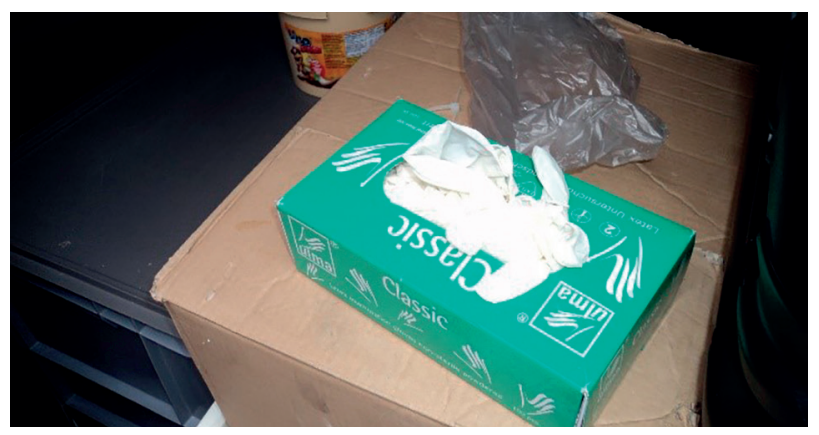

Slika 9.

Izvor: Jagić, Kecerin (2018.)
Slike 7,8 i 9 prikazuju sredstva za osobnu zaštitu prilikom uzimanja rasutih uzoraka.

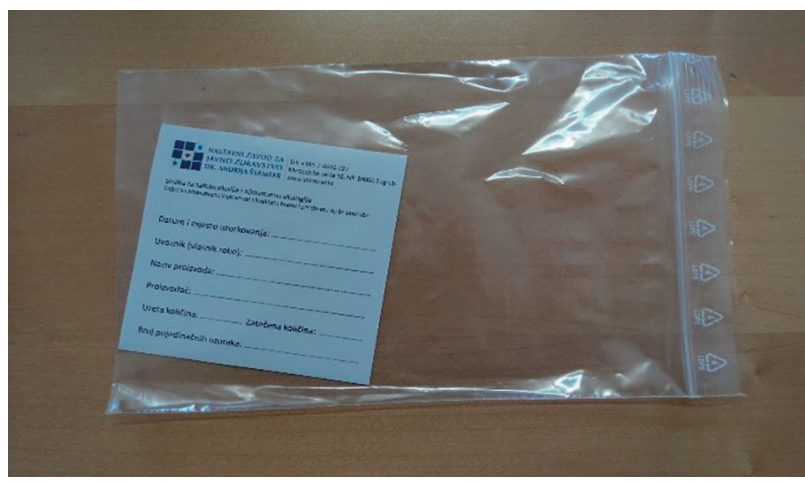

Slika 10. Naljepnice i vrećice za pakiranje i označavanje pojedinačnih uzoraka Izvor: Jagić, Kecerin (2018.)

\subsubsection{Postupak uzorkovanja sušenog voća u pojedinačnim pakiranjima}

Način uzorkovanja u pojedinačnim pakiranjima također je određen Uredbom komisije (EZ) br. 401/2006. Prilikom uzorkovanja pojedinačnih pakiranja valja voditi računa da je riječ o istoj seriji, šarži, lotu, datumu proizvodnje ili roku valjanosti. Učestalost uzimanja uzorka u pojedinačnom pakiranju određena je formulom:

Učestalost uzorkovanja $(\mathrm{SF}) \mathrm{n}=\frac{\begin{array}{c}\text { težina serije }(\mathrm{kg}) \times \text { težina } \\ \text { pojedinačnog uzorka }(\mathrm{kg})\end{array}}{\begin{array}{c}\text { težina skupnog uzorka }(\mathrm{kg}) \mathrm{x} \text { težina } \\ \text { pojedinačnog pakiranja }(\mathrm{kg})\end{array}}$

\subsubsection{Priprema uzorka za laboratorijsku obradu}

Prema Pravilniku o planu uzorkovanja i metodama analiza za službenu kontrolu količina mikotoksina u hrani (NN 45/08) i Uredbi (EZ) br. 401/2006, masa rasutog uzorka (rinfuza) koja se uzima za serije do 15 tona za analizu iznosi 30 kg. Skupni se uzorak miješa u tri jednaka laboratorijska uzorka (ili poduzorka) od $10 \mathrm{~kg}$. Svaki laboratorijski uzorak od $10 \mathrm{~kg}$ mora se posebno fino usitniti i dobro promiješati kako bi se postigla dobra homogenizacija. *

Da bi se olakšalo homogeniziranje velikih količina uzoraka dodaje se voda u omjeru uzorak: voda $=1: 1,5$. Nakon toga svaki pojedinačni uzorak od $10 \mathrm{~kg}$ dijeli se na tri laboratorijska uzorka, odvaguje u količini od $200 \mathrm{~g}$ i stavlja se u sterilnu PVC ambalažu.

* Napomena: Kada govorimo o sušenom voću, sušene smokve predstavljaju svojevrsnu iznimku jer zahtijevaju (ovisno o količini serije) uzimanje poduzoraka. Taj zahtjev za druge vrste sušenog voća ne postoji. 


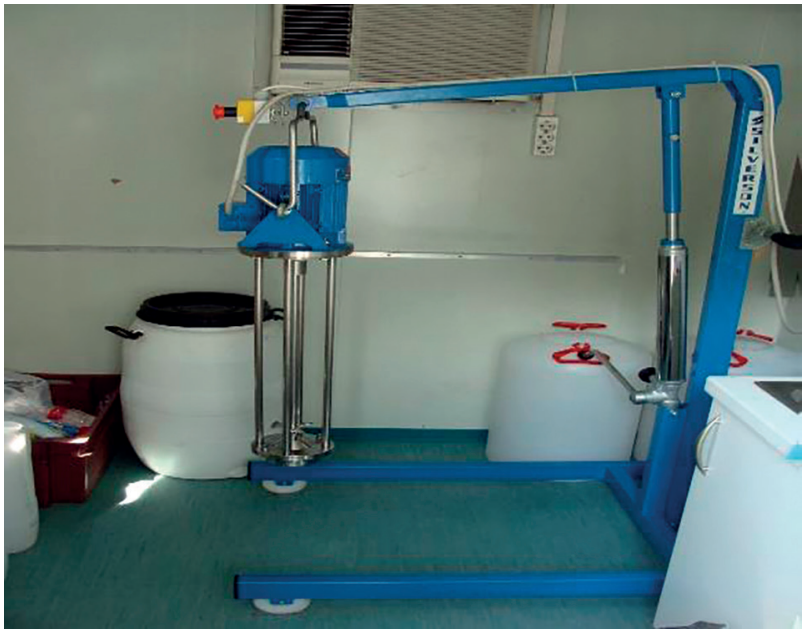

Slika 11. Uređaj i oprema za homogenizaciju Izvor: Bošnir i sur. (2014.), Uzorkovanje hrane i laboratorijske analize kontaminanata u svrhu procjene zdravstvene ispravnosti, Uvod u sigurnost hrane, Inštitut za sanitarno inženirstvo Slovenije

Laboratorije koji obavljaju analize mikotoksina u svrhu službenih kontrola mora ovlastiti Ministarstvo poljoprivrede. Laboratorij mora biti akreditiran za HRN EN ISO/ IEC 17025 za najmanje jednu vrstu mikotoksina u vezi s analitičkom tehnikom, a za sve ostale mikotoksine mora sudjelovati u programima međulaboratorijskih usporedbi te imati provedenu validaciju metoda.

Validacijom se potvrđuje da je odabrana analitička metoda prikladna za namijenjenu joj svrhu. To je postupak kojim se određuje i dokumentira prikladnost analitičkog sustava za određenu namjenu.
Akreditacija laboratorija (prema normi HRN EN ISO/IEC 17025) jest nepristran postupak koji vodi treća strana (Hrvatska akreditacijska agencija (HAA) te strani i domaći stručni ocjenitelji) kojim se potvrđuje kompetentnost za provedbu ispitivanja.

U skladu s Uredbom (EZ) br. 401/2006, akreditirani laboratorij mora imati odgovarajuću opremu za pripremu, obradu i homogenizaciju uzoraka. ${ }^{39}$

\subsection{Metode}

S obzirom na svojstva mikotoksina u smislu njihova pojavljivanja pri lošem skladištenju na velikim količinama hrane, na njihovu heterogenost u uzorcima te u pravilu velike količine koje se uzorkuju, prije analize valja dobro homogenizirati uzorak. Nakon toga primjenjuje se test ELISA (engl. Enzyme Linked Immunosorbent Assay) kao orijentacijska metoda koja nam može dati lažno pozitivne rezultate. Iz tog se razloga uzorci pozitivni na testu ELISA moraju analizirati nekom potvrdnom metodom kao što su tekućinska kromatografija visoke djelotvornosti (HPLC) ili tekućinska kromatografija s tandemskim spektrometrom masa (LC-MS/MS).

\subsubsection{Test ELISA}

ELISA je imunoenzimski test kojim se određuje koncentracija mikotoksina na načelu vezanja antigen - protutijelo. Komplet za određivanje mikotoksina u svojem pakiranju sadrži plastične jažice, standarde, reagense

\section{PODJELA LABORATORIJSKIH UZORAKA:}

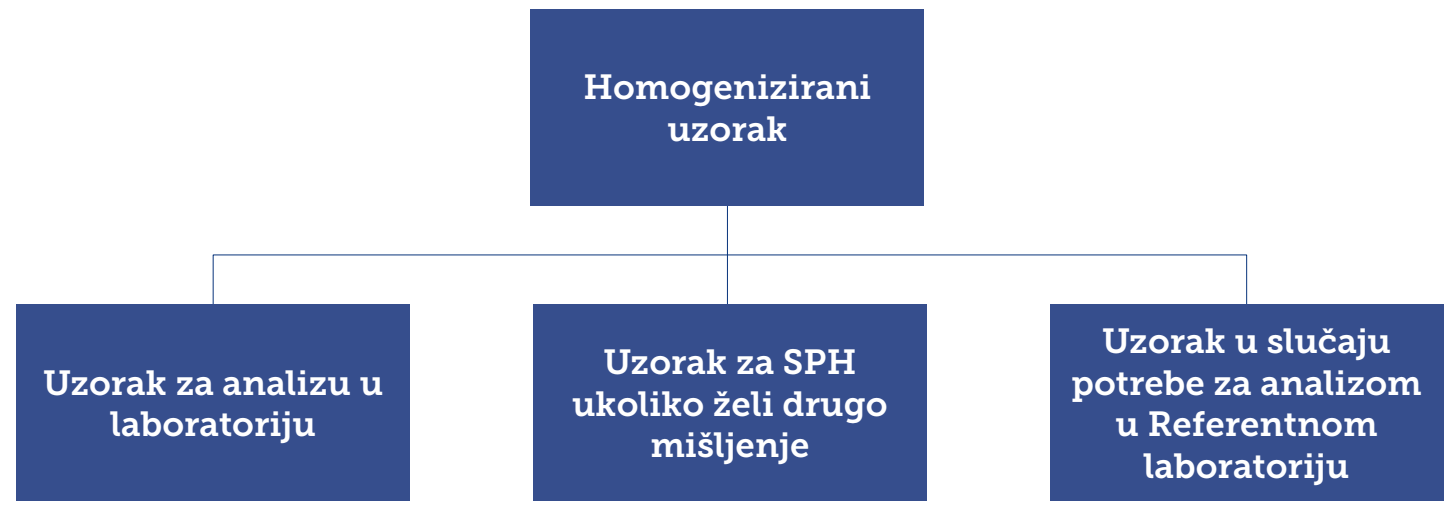

Slika 12. Shematski prikaz podjele homogeniziranog uzorka (Uredba komisije (EZ) br. 401/2006. o utvrđivanju metoda uzorkovanja i analize za službenu kontrolu razina mikotoksina u hrani) 
za provođenje testa te radne upute. Prije same imunološke reakcije antigen - protutijelo potrebno je pripremiti uzorak. Nakon homogenizacije i odvage, uzorku se dodaje otopina metanol : voda (70:30). Smjesu je tada potrebno staviti na tresilicu tri minute. Poslije homogenizacije uzorak se mora taložiti dvije do tri minute.

Da bismo smanjili neželjene učinke (interferencije) pojedinih sastojaka analiziranog uzorka (engl. matrix effect), npr. visoka razina šećera u sušenim smokvama, ekstrakt je potrebno profiltrirati kroz filtar (Whatman No. 1). Taj se ekstrakt zajedno s konjugatom stavlja u jažicu na čijem se dnu nalazi antigen. Nakon inkubacije od 15 minuta na sobnoj temperaturi jažice se isprazne te se dodaje supstrat koji uzorke oboji u plavo. Važno je napomenuti da je intenzitet obojenosti uzorka obrnuto proporcionalan količini analita. Inkubacija traje pet minuta u mraku na sobnoj temperaturi. Poslije toga dodaje se stop-otopina te se tako pripremljeni uzorak snima spektrofotometrijski. Kalibracijska se krivulja radi sa svakom serijom uzoraka, a koncentracija okratoksina A u uzorku očita se iz kalibracijskog pravca.

\subsubsection{Primjena HPLC-a u analizi okratoksina A}

Tekućinska kromatografija visoke djelotvornosti (metoda HPLC) jest kromatografska tehnika u kojoj se kao pokretna faza koristi tekućina, a nepokretna je faza krutina različite polarnosti. Komponente smjese razdvajaju se putovanjem kroz kolonu zbog kemijskih interakcija između tvari koja se analizira i nepokretne (stacionarne) faze u koloni. Pokretna (mobilna) faza jest tekućina visokog tlaka koja utječe na interakcije analita i nepokretne faze te se u analizama najčešće upotrebljava gradijentna promjena sastava pokretne faze. Najčešće su korištena otapala voda, metanol i acetonitril, kojima se dodaju različiti puferi ili neke druge komponente koje pogoduju razdvajanju analiziranih komponenata međusobno ili njihovom odvajanju od ostalih komponenata iz uzorka. Vrijeme zadržavanja komponenata ovisi o prirodi tvari koja se analizira i karakteristično je za određenu tvar. Primjena visokog tlaka povećava linearnu brzinu i daje komponentama manje vremena za zadržavanje, što poboljšava rezoluciju kromatograma i smanjuje vrijeme analize, uz uštedu otapala.

\subsection{Priprema uzorka}

Analizi na instrumentu prethodi priprema uzorka. Prva je faza homogenizacija uzorka uz dodatak vode. Nakon homogenizacije napravi se odvaga određene količine homogeniziranog uzorka u Erlenmayerovu tikvicu uz dodatak metanola $+0,1 \mathrm{molL}^{-1}$ fosforne kiseline da se olakša ekstrakcija. Sadržaj se 15 minuta miješa na magnetskoj miješalici te se filtrira kroz filtarski papir. Nakon toga se u laboratorijsku čašu se otpipetira potrebna količina filtrata i razrijedi fosfatnim puferom (PBS). Razrijeđeni se ekstrakt propusti kroz imunoafinitetnu kolonu (IAC), a protok se podesi prema uputama proizvođača kolona. Propuštanjem ekstrakta kroz imunoafinitetnu kolonu OTA (antigen) se veže na protutijela na čvrstom nosaču te ostaje u koloni. Važno je naglasiti da se punilo kolone ne smije osušiti nakon prolaska ekstrakta. Nakon što ekstrakt u potpunosti prođe, kolona se ispire destiliranom vodom te se osuši u vakuumu. Okratoksin A eluira se propuštanjem metanola. Eluat se skuplja u epruvetu i upari do suhog u struji zraka.

Ovom se metodom u krakom vremenu pročišćavanja uzorka dobiva dobra preciznost, točnost i osjetljivost za daljnju analizu, a također valja spomenuti i nastajanje manjih količina organskih otapala, kao i smanjenu izloženost zaposlenika koji izvode pripremu uzorka njihovu štetnom djelovanju. ${ }^{45}$

Nakon pripreme uzorka slijedi analiza na tekućinskom kromatografu - HPLC (Agilent 1100) koji se sastoji od otplinjača, termostatiranoga automatskog uzorkivača, binarne pumpe i FLD detektora (engl. fluorescence detection) te sustava za računalnu obradu podataka (slika 13).

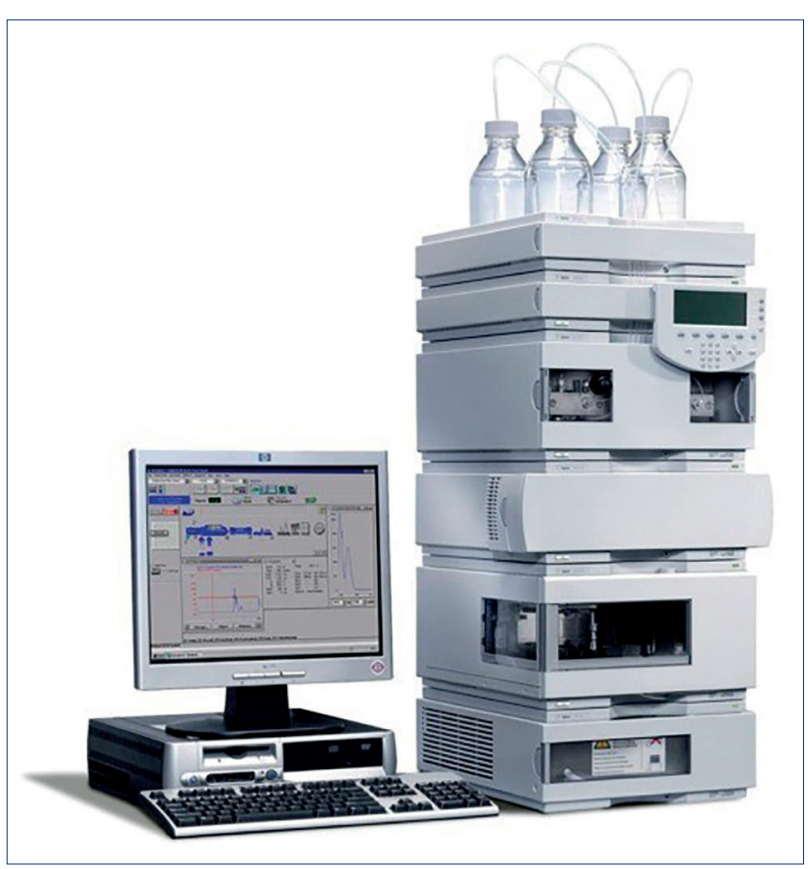

Slika 13. HPLC uređaj Agilent 1100

Izvor: https://gmi-inc.com/media/product/f47/agilent-1100-hplcsystem-vwd-with-quaternary-pump-949.jpg 


\section{Uvjeti kromatografiranja}

Kromatografirano je na reverzno-faznoj koloni ispunjenoj punilom tipa C18 (Luna 2,0 x $150 \mathrm{~mm}$, veličina čestica $3 \mu \mathrm{m}$ i promjera pora $100 \AA$; Phenomenex, Torrance, SAD). Početni sastav pokretne faze bio je $35 \%$ otopine mravlje kiseline u vodi $(0,2 \%)$ i $65 \%$ acetonitrila uz protok od $0,2 \mathrm{~mL} / \mathrm{min}$. Tijekom analize postotak acetonitrila povećavan je do $90 \%$. Temperatura kolone bila je $40^{\circ} \mathrm{C}$, a volumen injektiranja $30 \mu \mathrm{L}$. Nakon razdvajanja komponente su detektirane na FLD-u, ekscitacijska valna duljina bila je $247 \mathrm{~nm}$, a emisijska valna duljina bila je $480 \mathrm{~nm}$.

\subsection{Kontrola kvalitete rezultata analize}

Zbog važnosti koju ima vjerodostojnost ispitnih rezultata, kao i šteta koje mogu proizaći iz pogrešnih rezultata, svaki laboratorij mora voditi brigu o osiguravanju kvalitete ispitnih rezultata koje daje. Svi referentni laboratoriji za analizu mikotoksina dužni su svoje poslovanje i aktivnosti uskladiti sa zahtjevima navedenima u normi HRN EN ISO/IEC 17025. U spomenutoj normi navedene su određene metode s pomoću kojih se može osigurati zadovoljavajuća razina kvalitete. Ako laboratorij ima za cilj dokazati osposobljenost u radu, odnosno vjerodostojnost dobivenih rezultata, mora udovoljiti nizu uvjeta koji se odnose na sustav upravljanja (upravljački zahtjevi), kao i tehničke zahtjeve.

\section{Upravljački zahtjevi:}

- odgovarajuća organizacija (definirane odgovornosti)

- sprječavanje sukoba interesa

- uspostavljena odgovarajuća zaštita u pogledu povjerljivosti

- stručnost i sigurnost osoblja i informacija.

\section{Tehnički zahtjevi:}

- osoblje

- uvjeti smještaja i okoliša

- ispitne i umjerne metode i njihova validacija

- oprema

- mjerne sljedivosti

- uzorkovanja

- rukovanje predmetima za ispitivanje i umjeravanje.

Postoji velik broj načina kojima je moguće osigurati odnosno kontrolirati zadovoljavajuću razinu kvalitete u određenom laboratoriju. Navedimo samo neke:

- ispitivanja osposobljenosti (PT)

- međulaboratorijska ispitivanja (MLU)

- uporaba certificiranih referentnih materijala (CRM)

- uporaba referentnih materijala (RM).
Ispitivanja osposobljenosti jesu ispitivanja koja organiziraju tvrtke akreditirane za tu djelatnost. Pripremaju uzorak s analitima ovisno o vrsti testa i šalju ga u laboratorije prijavljene na test. Usporedba ovako dobivenih rezultata provodi se kako bi se postigli sljedeći ciljevi:

- validacija ispitnih postupaka i određivanje nesigurnosti rezultata

- procjena pouzdanosti rezultata ispitivanja onih laboratorija koji sudjeluju u međulaboratorijskim ispitivanjima.

Organizacija ispitivanja osposobljenosti provodi se ovisno o željenim ciljevima. Zahtjevi su propisani međunarodnim standardima (ISO 5725-2, ISO Guide 35, ISO 13528). Svi su rezultati povjerljivi, tako da nijedan laboratorij ne bi trebao imati rezultate drugih. Da bi ispitni laboratoriji mogli dokazati svoju mjeriteljsku sposobnost, moraju sudjelovati u usporedbenim mjerenjima, kako bi vidjeli kolika je mjerna nesigurnost ispitnih rezultata. Na temelju individualno dobivenih rezultata laboratoriji odlučuju o mogućim popravnim radnjama kako bi se unaprijedili postupci ispitivanja.

Međulaboratorijska ispitivanja laboratoriji organiziraju međusobno prema istim pravilima kao što se organiziraju i ispitivanja osposobljenosti, a ciljevi su im uglavnom isti. Primjenjuju se najviše kada nema organiziranih ispitivanja osposobljenosti za željene analite ili vrstu uzoraka u nekim udruženjima laboratorija kao što su policijski i vojni laboratoriji ili u nekim drugim specifičnim slučajevima. ${ }^{46}$

Referentni materijal (RM): materijal ili tvar čija je jedna ili više vrijednosti karakteristika dovoljno homogena i dobro utvrđena da se može primjenjivati za kalibriranje instrumenta, ocjenu metoda mjerenja ili dodjelu vrijednosti materijalima.

Certificirani referentni materijal (CRM): referentni materijal s priloženim certifikatom čija je jedna ili više vrijednosti karakteristika certificirana postupkom kojim se utvrđuje njegova sljedivost do precizne realizacije jedinice u kojoj su izražene vrijednosti karakteristika, a čija je svaka certificirana vrijednost popraćena nesigurnošću na navedenoj razini pouzdanosti. Pripravu certificiranih referentnih materijala provode „proizvođači referentnih materijala" (engl. reference material producers). ${ }^{47}$

\section{Unutarnja kontrola kvalitete}

\section{Injektiranje otopine radnog standarda (RS)}

Radni standardi priređuju se odgovarajućim razrjeđivanjem primarnog standarda pogodnim otapalom 
(acetonitril) u odmjernim tikvicama od $10 \mathrm{ml}$. Tako pripremljen radni standard čuva se u hladnjaku za referentne materijale $u$ ambalaži od tamnog stakla. Provjera stabilnosti radnih standarda vrši se dugoročnim praćenjem varijabilnosti mjerenja. Točne koncentracije, razrjeđenja te oznake standarda, kao i brojevi šarži potvrđenih referentnih materijala i njihov rok trajanja upisuju se u laboratorijski dnevnik priprave standarda.

Injektiranje otopine radnog standarda vrši se svaki dan prije početka mjerenja. U softver se upisuje koncentracija i datum pripreme standarda. Radni standard potrebno je injektirati do ustaljivanja retencijskog vremena (vrijeme zadržavanja pika dva uzastopna injektiranja ne razlikuje se više od $\pm 2,5 \%$, prema odluci Komisije o primjeni Direktive Vijeća 96/23/EZ o provođenju analitičkih metoda i tumačenju 2002/657/ EC, točka 2.3.5.1). Površine dobivene kao rezultat dva uzastopna injektiranja i vremena zadržavanja upisuju se u kontrolnu kartu i moraju se nalaziti unutar dva standardna odstupanja odziva RS-a $( \pm 2$ s) injektiranog kroz određeni period (preporuka: najmanje 30 radnih dana). U suprotnom se priprema nova otopina RS-a. Ako je odziv novog RS-a izvan propisanih granica, utvrđuje se razlog odstupanja.

\section{Validacija metode}

Parametri validacije i kriteriji prihvatljivosti preuzeti su iz Uredbe komisije (EZ) br. 401/2006 o utvrđivanju meto- da uzorkovanja i analize za službenu kontrolu razina mikotoksina u hrani, točka 4.3.1. i navedeni su u tablici 1.

Svi navedeni parametri ispitani su tijekom validacije metode u laboratoriju i dobiveni su zadovoljavajući rezultati, čime je dokazana osposobljenost za provođenje ovih ispitivanja.

\section{Rasprava}

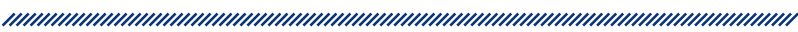

Premda su proizvodi od sušenog voća glavna tema ovog rada, nije na odmet spomenuti i ostale vrste hrane u kojima OTA svojom prisutnošću negativno djeluje kako na kvalitetu prehrambenog proizvoda tako i na njegovu sigurnost te posljedično na zdravlje populacije. Prisutnost okratoksina A potvrđena je u mnogim vrstama hrane kao što su mahunarke, žitarice, suhomesnati i fermentirani proizvodi, kakao, sok od grejpa, zelena kava, kruh, vino, pivo te voćni sokovi. Dobar dio nabrojenih prehrambenih proizvoda svakodnevno je zastupljen u prehrani stanovnika u Republici Hrvatskoj. Iz toga možemo zaključiti da postoji opravdana bojazan za zdravlje potrošača koje može biti narušeno nedvojbeno negativnim utjecajem okratoksina $A$.

\begin{tabular}{|c|c|}
\hline Parametar & Kriterij prihvatljivosti \\
\hline Selektivnost & $R_{s} \geq 1,3$ \\
\hline Iskorištenje & $\begin{array}{c}<1 \mu \mathrm{kg}^{-1} \rightarrow 50 \text { do } 120 \% \%^{\mathrm{a}} \\
1 \text { do } 10 \mu \mathrm{kg}^{-1}=50 \text { do } 110 \%\end{array}$ \\
\hline Istinitost & $100 \pm 25 \%$ b \\
\hline Preciznost mjerenja & $\mathrm{RSD} \leq 5 \%{ }^{\mathrm{b}}$ \\
\hline Preciznost pripreme radnog standarda & RSD $5 \%^{\mathrm{b}}$ \\
\hline Preciznost pripreme uzorka & $\begin{array}{l}<1 \mu \mathrm{g} \mathrm{kg}^{-1} \rightarrow \mathrm{RSD}_{\mathrm{r}} \leq 40 \%^{\mathrm{a}} \\
1-10 \mu \mathrm{kg}^{-1} \rightarrow \mathrm{RSD}_{\mathrm{r}} \leq 20 \%^{\mathrm{a}}\end{array}$ \\
\hline Međupreciznost & $\begin{array}{l}<1 \mu \mathrm{g} \mathrm{kg}^{-1} \rightarrow \mathrm{RSD}_{\mathrm{R}} \leq 60 \% \%^{\mathrm{a}} \\
1-10 \mu \mathrm{kg}^{-1} \rightarrow \mathrm{RSD}_{\mathrm{R}} \leq 30 \% \%^{\mathrm{a}}\end{array}$ \\
\hline Linearnost & $k \geq 0,999$ \\
\hline Granica detekcije & $\leq \mathrm{MDK} / 3\left(\mu \mathrm{g} \mathrm{kg}^{-1}\right)^{\mathrm{b}}$ \\
\hline Granica kvantifikacije & $\leq \mathrm{MDK} / 2\left(\mu \mathrm{g} \mathrm{kg}^{-1}\right)^{\mathrm{b}}$ \\
\hline Robustnost & Informacija \\
\hline
\end{tabular}


Posljedice su djelovanja okratoksina A na ljudski organizam višestruke. Nepobitno je dokazan nefrotoksičan, genotoksičan i karcinogeni učinak okratoksina A na pokusnim i domaćim životinjama. Kod ljudi izloženost niskim razinama okratoksina A zajedno s drugim vrstama mikotoksina, što je najčešći slučaj, može rezultirati sinergijskim ili aditivnim učincima u konačnici izazivajući genotoksičnost i/ili karcinogenost te time ozbiljno utjecati na zdravlje. ${ }^{48}$

U tom kontekstu potrebno je posebno istaknuti balkansku endemsku nefropatiju (BEN). Balkanska endemska nefropatija kronična je tubulointersticijska nefropatija udružena s karcinomima gornjeg dijela urotela. Naime, iako postoje prijepori u stručnim krugovima glede uzroka spomenute bolesti, što je već ranije spomenuto, uloga okratoksina A i mikotoksina općenito nije u potpunosti odbačena. Tome u prilog treba spomenuti i mnoga istraživanja kojima je dokazana povišena razina okratoksina A u krvi stanovnika zahvaćenog područja (Podunavlje i Brodska Posavina). U tim je regijama pojava tumora gornjeg dijela urotela oko 55 puta veća nego u drugim dijelovima Hrvatske. ${ }^{48}$

lako je važnost mikotoksina općenito u smislu sigurnosti hrane i zdravlja potrošača prepoznata te dobrim dijelom kvalitetno popraćena zakonskom regulativom, ipak postoji potreba da se to područje znatno bolje uredi. Jedan su od primjera koji idu u prilog toj tvrdnji i razne vrste sušenog voća. Naime, zakonodavstvo EUa propisuje MDK za okratoksin A samo u sušenim grožđicama, najviše granice za ostale vrste sušenog voća nisu zakonski određene. $U$ tom slučaju, s obzirom na nedvojbeno negativan utjecaj mikotoksina općenito na ljudsko zdravlje, primjenjuje se Načelo predostrožnosti navedeno u Zakonu o hrani (NN 81/13). Takva situacija u kontekstu prilično učestalih obavijesti putem RASFF-a (grafikon 1) koje se odnose na sušeno voće, prosječnih godišnjih srednjih vrijednosti okratoksina $A$ u sušenom voću (grafikon 2), kao i spomenuta zakonska neuređenost za veliki broj vrsta sušenog voća osim grožđica predstavlja veliki izazov za sve zainteresirane strane.

S obzirom na prethodno spomenuti negativni učinak okratoksina A na ljudsko zdravlje, problem se pokušava riješiti postavljanjem privremeno dopuštenog tjednog unosa - PTWI (engl. the provisional tolerable weekly intake) koji iznosi 100 ng po kilogramu tjelesne mase. Tu razinu postavila je JECFA (The Joint FAO / WHO Expert Committee on Food Additives) ${ }^{42}$ Europska agencija za hranu EFSA (engl. European Food Safety Authority) preporučuje nešto veću granicu od 120 ng po kilogramu tjelesne mase. U kontekstu neuređenosti legislative valja spomenuti i tradicionalne suhomesnate proizvode koji su znatno zastupljeni u prehrambenim navikama stanovnika Republike Hrvatske, a poglavito u područjima zahvaćenima balkanskom endemskom nefropatijom. Hrvatska agencija za hranu 2016. godine izradila je procjenu izloženosti okratoksina $\mathrm{A}$ u tradicionalnim suhomesnatim proizvodima (kulen, panceta, slavonska kobasica, dimljena šunka, dimljena rebra). Zaključeno je da je TWI premašen jedino u slučaju pancete ( $0,8 \%$ populacije), dok za ostale proizvode ne postoji vjerojatnost izloženosti ljudi iznad vrijednosti tjednog unosa (TWI). ${ }^{49}$

Novije analize prehrambene izloženosti okratoksinu A odraslih potrošača u Europi pokazale su da je tjedna izloženost u rasponu od 15 do 60 ng okratoksina A po kilogramu tjelesne težine tjedno. Srećom, ta je izloženost ispod TWI vrijednosti od 120 ng po kilogramu tjelesne mase, međutim postojeće baze podataka o potrošnji EFSA-e ne uključuju dojenčad i djecu. Stoga je EFSA-in panel CONTAM u svojem znanstvenom mišljenju zaključio da će više podataka biti potrebno za procjenu stope izloženosti ovog segmenta potrošača, uzimajući u obzir njihove prehrambene sklonosti. ${ }^{50}$ Također je potrebno napomenuti da neke kategorije hrane nisu dovoljno opisane i analizirane na prisutnost okratoksina $A$, uključujući voćne sokove (osim soka od grožđa) te stoga nisu uzete u obzir u spomenutom EFSA-inu mišljenju o procjeni zbog njihove niske razine zagađenja okratoksinom $\mathrm{A}(0,1 \mathrm{i} 0,01 \mu \mathrm{g} / \mathrm{kg})$. Slično tome, suho voće i začini nisu uzeti u obzir zbog njihove niske potrošnje od 2,9 i 0,5 grama dnevno. ${ }^{51}$

\section{Zaključak}

Svakako bi bilo potrebno provesti istraživanje o prehrambenim navikama stanovnika EU-a da se utvrdi zastupljenost suhog voća u ukupnoj prehrani u cilju postavljanja MDK-a za trenutačno nedefinirane vrste sušenog voća. No u tome postoji niz poteškoća koje su povezane s podnebljem, navikama ili kulinarskom tradicijom pojedinih regija ili država unutar EU-a. Spomenute razlike zasigurno bi utjecale na kvalitetu, točnost $i$ primjenjivost dobivenih rezultata u nekoj budućoj procjeni rizika koja bi bila temelj za određivanje graničnih vrijednosti za navedene proizvode.

Premda tijekom tog procesa postoji niz prepreka, treba nastojati da se spomenuta problematika što je moguće prije riješi i uvrsti u pripadajuću zakonsku regulativu, 
iako je to ponekad vrlo trnovit put jer veliki proizvođači uvijek preko lobističkih skupina ometaju takve namjere te uvijek teže da MDK bude što je moguće viši.

Unatoč svim tim izazovima, kroz kvalitetan rad unutar zemalja članica EU-a u smislu kontinuiranog praćenja nereguliranih mikotoksina, suradnju nacionalnih i međunarodnih institucija kako bi se osigurale nužne informacije u svrhu donošenja kvalitetnih i mjerodavnih zaključaka, kvalitetno provedene procjene rizika, kvalitetno praćenje trendova različitih mikotoksina u hrani i praćenja prehrambenih navika stanovništva određenog područja moguće je pomiriti različite grupacije i njihove interese te u konačnici osigurati da hrana s tržišta EU-a bude sigurna za zdravlje potrošača.

\section{Referencije}

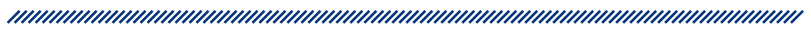

1. Ožegović L, Pepeljnjak S. Mikotoksikoze. Zagreb: Školska knjiga; 1995.

2. Oliveira CAF. Recent trends in microbiological decontamination of aflatoxins in foodstuffs. Aflatoxins-Recent Advances and Future Prospects. 2013; 1: 59-62.

3. Iqbal SZ, Bhatti IA, Asi MR, Zuber M, Shahid M, Parveen I. Effect of $\gamma$ irradiation on fungal load and aflatoxins reduction in red chillies. Radiat Phys Chem. 2013; 82: 80-84.

4. [CAST] Council for Agricultural Science and Technology. Mycotoxins: economic and health risks. Task force report no. 116. Ames, lowa: Council for Agricultural Science and Technology. 1989.

5. Pitt Jl. Toxigenic fungi and mycotoxins. Br Med Bull. 2000; 56: 184-192.

6. Bennett JW, Klich M. Mycotoxins. Clin Microbiol Rev. 2003; 16: 497-516.

7. Bhat R, Sridhar KR, Karim AA. Microbial quality evaluation and effective decontamination of nutraceutically valued lotus seeds by electron beams and gamma irradiation. Radiat Phys Chem. 2010; 79: 976-981.

8. Grosso F, Saïd S, Mabrouk I, Fremy JM, Castegnaro M, Jemmali M, Dragacci S. New data on the occurrence of ochratoxin A in human sera from patients affected or not by renal diseases in Tunisia. Food Chemistry and Toxicology. 2003; 41(8): 1133-1140.

9. Maaroufi K, Achour A, Betbeder AM, Hammami M, Ellouz F, Creppy EE. Foodstuffs and human blood contamination by ochratoxin A: A correlation with chronic interstitial nephropathy inTunisia. Archives of Toxicology. 1995; 69(8): 552-558.

10. Coronel MB, Sanchis V, Ramos AJ, Marin S. Assessment of the exposure to ochratoxin A in the province of Lleida, Spain. Food and Chemical Toxicology. 2009; 47(11): 2847-2852.
11. Speijers GJA, VanEgmond HP. Worldwide ochratoxin A levels in food and feeds. U: Creppy E, Castegnaro M, Dirheimer G (ur.). Human Ochratoxicosis and its Pathologies. Pariz: John Libbey; 1993; 85-100.

12. Zimmerli B, Dick R. Determination of toxigenic ochratoxin $A$ at the ppt level in human blood, serum, milk and some foodstuffs by high-performance liquid chromatography with enhanced fluorescence detection and immunoaffinity column cleanup: methodology and Swiss data. Journal of Chromatography and Biomedical Sciences. 1995; 666(1): 85-99.

13. Martins ML, Martins HM, Gimeno A. Incidence of microflora and of ochratoxin A in green coffee beans (Coffea arabica). Food Additives and International Journal of Food Microbiology Contaminants. 2003; 20(12): 1127-1131.

14. Zinedine A, Juan C, Idrissi L, Mañes J. Ochratoxin A in bread consumed in Morocco. Microchemistry Journal. 2007; 87(2): 154-158.

15. Zinedine A, Soriano JM, Juan C, Mojemmi B, Moltó JC, Bouklouze A, Cherrah, Idrissi L, El Aouad R, Mañes J. Incidence of ochratoxin $A$ in rice and dried fruits from Rabat and Salé area, Morocco. Food Additives and Contaminants. 2007; 24(3): 285-291.

16. Filali A, Betbeder AM, Baudrimont I, Benayada A, Souleymani R, Creppy EE. Ochratoxin A in human plasma in Morocco: A preliminary survey. Human Experimental Toxicology. 2002; 21(5): 241-245.

17. Abarca ML, Accensi F, Bragulat MR, Castella G, Cabañes FJ. Aspergillus carbonarius as the main source of ochratoxin A contamination in dried vine fruits from the Spanish market. Journal of Food Protection. 2003; 66(3): 504-506.

18. Samson RA, Hoekstra ES, Lund F, Filtenborg O, Frisvad JC. Methods for the detection, isolation and characterisation of foodborne fungi. U: Samson RA, Hoekstra ES, Frisvad JC, Filtenborg O (ur.). Introduction to food and airborne fungi. Centraalbureau voor Schimmelcultures. Utrecht: 2000; 283-297.

19. Sage L, Garon D, Seigle-Murandi F. Fungal microflora and ochratoxin A risk in French vineyards. Journal of Agriculture and Food Chemistry. 2004; 52(18): 5764-5768.

20. Ostry V, Ruprich J, Skarkova J, Prochazkova I, Kubatova A. MYKOMON-monitoring project of toxigenic fungi in food in years 1999-2001. Mycotoxin Research. 2002; 18A(2): 193-197.

21. Wafa EW, Yahya RS, Sobh MA, Eraky I, El-Baz M, El-Gayar HAM, Betbeder AM, Creppy EE. Human ochratoxicosis and nephropathy in Egypt: A preliminary study. Human Chromatography and Biomedical Sciences, Experimental Toxicology. 1998; 17(2): 124-129.

22. Romero SM, Comerio RM, Larumbe G, Ritieni A, Vaamonde G, Pinto V. Toxigenic fungi isolated from dried vine fruits in Argentina. International Journal of Food Microbiology. 2005; 104(1): 43-49.

23. Zinedine A, Mañes J. Occurrence and legislation of mycotoxins in food and feed from Morocco. Food Control. 2009; 20(4): 334-344. 
24. Leong SL, Hocking AD, Pitt JI. Occurrence of fruit rot fungi (Aspergillus section Nigri) on some drying varieties of irrigated grapes. Australian Journal of Grape and Wine Research. 2004; 10(1): 83-88.

25. Monaci L, Palmisano F. Determination of ochratoxin A in foods: State of the art and analytical challenges. Analytical and Bioanalytical Chemistry. 2004; 378(1): 96-103.

26. Vettorazzi A, López de Cerain A. Mycotoxins as Food Carcinogens. U: Viegas C, Pinheiro C, Sabino R, Viegas S, Brandão J, Veríssimo C (ur.). Environmental Mycology in Public Health - Fungi and Mycotoxins Risk Assessment and Management. Elsevier Inc. 2015. 17. poglavlje.

27. Jelaković B, Dika Ž, Karanović S, Vuković Lela I. Endemska nefropatija u Hrvatskoj. Liječnički vjesnik. 2015; 137: 100-108.

28. Crosby LM, Tatu CA, Pavlović N, Orem WH. The Continuing Medical Mystery of Balkan Endemic Nephropathy. Journal of Rare Disorders. 2015; 2 (3): 28.

29. Palumbo JD, O'keeffe TL, Ho YS, Santillan CJ. Occurrence of Ochratoxin a Contamination and Detection of Ochratoxigenic Aspergillus Species in Retail Samples of Dried Fruits and Nuts. Journal of Food Protection. 2015; 78 (4): 836-842.

30. Kollia E, Kanapitsas A, Markaki P. Occurrence of aflatoxin $B_{1}$ and ochratoxin $A$ in dried vine fruits from Greek market. Food Additives \& Contaminants. 2013; Part B, 1 (7): 11-16.

31. Nayebpoor F, Momeni M, Dehkordi FS. Incidence of Ochratoxin A in Raw and Salted Dried Fruits Using High Performance Liquid Chromatography. American-Eurasian Journal of Toxicological Sciences. 2013; 5 (1): 1-6.

32. Solfrizzo M, Piemontese L, Gambacorta L, Zivoli R, Longobardi F. Food Coloring Agents and Plant Food Supplements Derived from Vitis vinifera: A New Source of Human Exposure to Ochratoxin A. Agric. Food Chem. 2015; 13 (63): 3609-3614.

33. Kanapitsas A, Batrinou A, Aravantinos A, Sflomos C, Markaki P. Gamma radiation inhibits the production of Ochratoxin A by Aspergillus carbonarius. Development of a method for OTA determination in raisins. Food Bioscience. 2016; (15): 42-48.

34. Ozer H, Oktay Basegmez HI, Ozay G. Review Mycotoxin risks and toxigenic fungi in date, prune and dried apricot among Mediterranean crops. Phytopathologia Mediterranea. 2012; 51 (1): 148-157.

35. Hakobyan L, Grigoryan K, Trchounian A. The dynamics of ochratoxigenic fungi contents through different stages of dried grape production. BIO Web of Conferences. 2017; 9: 6.

36. Heperkan D, Moretti A, Dikmen CD, Logrieco AF. Toxigenic fungi and mycotoxin associated with figs in the Mediterranean area. Phytopathologia Mediterranea. 2012; 51(1): 119-130.

37. Uredba Komisije (EZ) br. 401/2006 od 23. veljače 2006. o utvrđivanju metoda uzorkovanja i analize za službenu kontrolu razina mikotoksina u hrani (konsolidirana verzija - svibanj 2014.). Dostupno na: https://eur-lex.europa.eu/legalcontent/HR/TXT/PDF/?uri=CELEX:32006R0401\&from=HR
38. Pravilnik o planu uzorkovanja i metodama analiza za službenu kontrolu količina mikotoksina u hrani (NN 45/08). Dostupno na: https://narodne-novine.nn.hr/ clanci/sluzbeni/2008_04_45_1532.html

39. Ivešić M. Sustavna kontrola mikotoksina i biljnih toksina u hrani i hrani za životinje. 2015. Dostupno na: http:// cdn.podravka.net/repository/files/3/5/35fc46b48e21e9 0baa210e748d7a219b.pdf (pristupljeno 4.6.2018.).

40. Zakon o kontaminantima (NN39/13). Dostupno na: https:// narodne-novine.nn.hr/clanci/sluzbeni/2013_04_39_721. html

41. Uredba Komisije (EZ) br. 1881/2006. o utvrđivanju najvećih dopuštenih količina određenih kontaminanata u hrani (konsolidirana verzija 2018.). Dostupno na: https:// eur-lex.europa.eu/legal-content/HR/TXT/PDF/?uri=CELE $\mathrm{X}: 32006 \mathrm{R} 1881 \&$ from $=\mathrm{HR}$

42. Zakon o hrani (NN 81/13). Dostupno na: https://narodne-novine.nn.hr/clanci/sluzbeni/2013_06_81_1699.html

43. Motarjemi Y, Moy G, Todd E. (ur.). Encyclopedia of Food Safety. 1. izd. Amsterdam: Elsevier/Academic Press; 2014.

44. Heperkan D, Moretti A, Dikmen CD, Logrieco AF. Toxigenic fungi and mycotoxin associated with figs in the Mediterranean area. Phytopathologia Mediterranea. 2012; 51(1): 119-130.

45. Wilcox J, Donnelly C, Leeman D, Marley E. The use of immunoaffinity columns connected in tandem for selective and cost-effective mycotoxin clean-up prior to multi-mycotoxin liquid chromatographic-tandem mass spectrometric analysis in food matrices. Journal of Chromatography A. 2015; 1400: 91-97.

46. CompaLab - The institute that organises proficiency tests for laboratories. Dostupno na: http://www.compalab.org/ (pristupljeno 29.7.2018.).

47. Sljedivost prema certificiranim referentnim materijalima. Dostupno na: http://www.svijet-kvalitete.com/index.php/umjeravanje/1323-sljedivost-prema-certificiranim-referentnim-materijalima (pristupljeno 27.7.2018.).

48. Peraica M, Flajs D, Domijan AM, Ivić D, Cvjetković B. Ochratoxin A Contamination of Food from Croatia. Toxins 2010, 2, 2098-2105; doi:10.3390/toxins2082098

49. Prikupljanje podataka i izvještavanje o (ne)reguliranim mikotoksinima u $\mathrm{RH}$. Dostupno na: http:// www.ptfos.unios.hr/CroMycoScreen/wp-content/ uploads/2016/10/05_Petric-Prikupljanje-podataka-iizvje\%C5\%A1tavanje-o-nereguliranim-mikotoksinimau-RH.pdf (pristupljeno 12.9.2018.).

50. Opinion of the Scientific Panel on contaminants in the food chain [CONTAM] related to ochratoxin A in food; Panel on Contaminants in the Food Chain; EFSA, 2006. DOI: 10.2903/j.efsa.2006.365.

51. WHO-GEMS/Food (World Health Organization-Global Environment Monitoring System/Food Contamination Monitoring and Assessment Programme), 2003. Food regional diets. Regional per Capita Consumption of Raw and Semiprocessed Agricultural Commodities, revizija: rujan 2003. ISBN 924159108 0. Svjetska zdravstvena organizacija (World Health Organization), Ženeva, Švicarska. 


\section{CONTROL OF OCHRATOXIN A IN DRIED FRUIT}

1 Robert Kecerin

1 Marinko Petrović

1 Ivana Prskalo

1 Vedran Jagić

1 Dario Lasić

1 Andrija Štampar Teaching Institute of Public Health, Zagreb

\section{Summary}

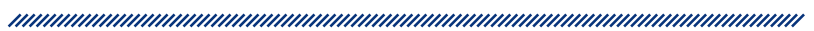

Ochratoxins are a subgroup of mycotoxins produced by molds of the genera Aspergillus ochraceus and Penicillium viridicatum. The most examined and most toxic is ochratoxin A (OTA), while less toxic are ochratoxin B and ochratoxin $\mathrm{C}$, obtained only in laboratory. Experimental tests on animals have proven nephrotoxic, carcinogenic, teratogenic and immunosuppressive effects of ochratoxin $\mathrm{A}$, and recent studies have shown that it causes adverse effects on reproductive health of humans. OTA is most commonly produced on crops after harvest of cereals, but it also represents a significant health problem and economic loss in production, processing, storage and distribution of other crops such as spices, coffee, legumes, nuts, wine, beer, dried fruit, etc.

Because of a lot of important nutrients (polyphenols, fibers, vitamins, minerals, etc.), dried fruit is produced around the world, so in many countries it makes a significant share in the agricultural production and in the economy. The appearance of mold, and consequently ochratoxin A, is the biggest problem in the cultivation, production and distribution of this type of food. The protection of the product from the appearance of mold and mycotoxins begins on the plantation itself, and it is necessary to carry it continuously through various production and manipulative phases (harvesting, drying, transporting, storage etc.).

For determination of mycotoxins in dried fruit and prevention of any potential safety threats in food being placed on the market, sensitive analytical methods for their detection and quantification, preferably the ELISA test as a screening method or HPLC as a confirmatory method are used. For most accurate data obtained in laboratory analyses, it is necessary to take the sample properly, and perform the analysis from well homogenized laboratory sample.

Keywords: mycotoxins, ochratoxin A, dried fruit, HPLC. 